\title{
Impact of Business Ecosystem on Green Business
}

\begin{abstract}
An ecosystem is a complex network or interconnected system. The network of organizations, including suppliers, distributors, customers, competitors, government agencies and so on, involved in the delivery of a specific product or service through both competition and cooperation is known as business ecosystem. The purpose of the research has two objectives: firstly, to clarify the definition of "green business", secondly, to find out whether there is any impact of normal business ecosystem on the green business activities. It would also indicate the environmental awareness the fast food giants are portraying and the practices followed by them to make them to be called as a green business.
\end{abstract}

Key words: Green Business, Environmental Awareness practices

\section{INTRODUCTION}

\section{ECO SYSTEM}

An ecosystem is a complex network or interconnected system.The network of organizations, including suppliers, distributors, customers, competitors, government agencies and so on, involved in the delivery of a specific product or service through both competition and cooperation is known as business ecosystem. The idea is that each business in the "ecosystem" affects and is affected by the others, creating a constantly evolving relationship in which each business must be flexible and adaptable in order to survive, as in a biological ecosystem.
All business functions within an ecosystem because if they are not cooperation then they are competing. Competition can take place directly or indirectly. Therefore, a business that isn't actively competing may still be the target of a larger organization that is out to dominate the market, thus making the smaller business indirectly part of the ecosystem by its mere existence and production of a product or service.

\section{GREEN BUSINESS OR SUSTAINABLE BUSINESS}

Sustainable business, or green business, is an enterprise that has minimal negative impact on the global or local environment, community, society, or economy, a business that strives to meet the triple bottom line. Often, sustainable businesses have progressive environmental and human rights policies. In general, business is described as green if it matches the following four criteria:

1. It incorporates principles of sustainability into each of its business decisions.

2. It supplies environmentally friendly products or services that replace demand for non-green products and/or services.

3. It is greener than traditional competition.

4. It has made an enduring commitment to environmental principles in its business operations.

The Brundtland Report emphasized that sustainability is a three-legged stool of people, planet, and profit. Sustainable businesses with the supply chain try to balance all three through the triple-bottom-line 
concept-using sustainable development and sustainable distribution to affect the environment, business growth, and the society.

Sustainability is often confused with corporate social responsibility (CSR), though the two are not the same. Bansal and DesJardine (2014) state that the notion of 'time' discriminates sustainability from CSR and other similar concepts. Whereas ethics, morality, and norms permeate CSR, sustainability only obliges businesses to make intertemporal trade-offs to safeguard intergenerational equity. Short-termism is the bane of sustainability.

Green business has been seen as a possible mediator of economic-environmental relations, and if proliferated, would serve to diversify our economy, even if it has a negligible effect at lowering atmospheric $\mathrm{CO} 2$ levels. The definition of "green jobs" is ambiguous, but it is generally agreed that these jobs, the result of green business, should be linked to clean energy, and contribute to the reduction of greenhouse gases. These corporations can be seen as generators of not only "green energy", but as producers of new "materialities" that are the product of the technologies these firms developed and deployed.

\section{REVIEW OF LITERATURE}

John Elkington TOWARDS A SUSTAINABLE CORPORATION: WIN-WIN BUSINESS STRATEGIES FOR SUSTAINABLE DEVELOPMENT

CaliforniaManagementReview, Vol.36 No.2, winter 1994; (pp.90-100) DOI: 10.2307/41165746

From the sustainable development policies of farsighted governments to the increasing environmental awareness- and cynicism - of consumers, a range of pressures is being brought to bear on business to improve its environmental performance. This article traces the development of some of those pressures, highlighting industries in the firing line, and examining some of the concerns of consumers. It looks at the ways in which companies can turn the environment game into one in which they, their customers, and the environment are all winners. It also explores the rapidly expanding area of corporate environmental reporting, including forms of environmental disclosure, target audiences, and leading exponents of the field.

Aditya Ghose, Konstantin Hoesch-Klohe, LotharHinsche, Lam-Son Le GREEN BUSINESS PRECESS MANAGEMENT

We have provided a roadmap for research and development in this nascent area of carbon-aware "green" business process management. We have provided a detailed description of the machinery for assessing the carbon-footprint of process designs, and outlined how this might be leveraged in process improvement, both at the single process level and at the level of networks of inter-operating processes. There is much to be done, and this paper should serve as a call to arms.

With increasingly onerous legislative and regulatory environmental obligations that business processes must satisfy, compliance management has emerged as a critical component of green BPM. There are two key aspects of compliance management: (1) compliance checking and (2) noncompliance resolution. Both exercises could be conducted in the context of process designs or process instances. Design-time compliance checking requires us to establish that process designs do not violate compliance requirements while run-time compliance checking requires us to establish the same for process instances.

\section{OBJECTIVES}

1) To know the effects of carrying out green business activities.

2) To know the impact of business ecosystem on green business.

3) To provide any required suggestions after the analysis.

\section{RESEARCH DESIGN}

1) Sources of Data: 
The primary data is collected by interacting personally with the businesses who have adopted the concept of green business and the secondary data is collected by various relevant websites and research articles.

2) Sampling Design:

a) Population: The population taken into consideration are the fast food giants in Bengaluru.

b) Sampling Frame: Fast Food giants in Mantri Square mall Malleshwaram, Bengaluru.

c) Sample Size: 27 (employees)

d) Sampling Technique: The method used to select the sample is a type of nonprobability sampling named as Convenience Sampling.

3) Tools for Data Collection: Tool used to gather the required information of this study is questionnaire.

\section{DATA COLLECTED (SECONDARY DATA)}

\section{STRATEGIES USED BY BUSINESSES TO GO GREEN}

Not all eco-strategies can be incorporated into a company's Eco-portfolio immediately. The widely practiced strategies include:

\section{Innovation \& Technology}

This introverted method of sustainable corporate practices focuses on a company's ability to change its products and services towards less waste production and sustainable best practices.

\section{Collaboration}

The formation of networks with similar or partner companies facilitates knowledge sharing and propels innovation.

\section{Process Improvement}

Continuous process surveying and improvement is essential to reduction in waste. Employee awareness of company-wide sustainability plan further aids the integration of new and improved processes.

\section{Sustainability Reporting}

Periodic reporting of company performance in relation to goals. These goals are often incorporated into the corporate mission (as in the case of Ford Motor Co.).

\section{Greening the Supply Chain}

Sustainable procurement is important for any sustainability strategy as a company's impact on the environment is much bigger than the products that they consume. The B Corporation (certification) model is a good example of one that encourages companies to focus on this.

\section{BUSINESSES GOING GREEN}

\section{General Electric:}

General Electric's presence on this list might surprise you, but the steps they have taken toward green operations are undeniable. Since 2006, the company has sold over $\$ 12$ billion of its Ecomagination products (including solar panels). For those who are still upset at GE's polluting of the Hudson River with polychlorinated biphenyls, the company is also making headway on an ambitious cleanup of that area. Barring further setbacks, the river should be cleaned up to a much better state in just a couple of years!

\section{McDonalds:}

Time was not long ago when McDonalds wouldn't have come within striking distance of making this list. However, the increasing public shift toward greener living has sent a clear signal to the powers that be at the popular fast-food chain. Instead of ravaging the natural habitats of animals, McDonalds now works in close collaboration with PETA on systematically reforming its business practices to be more humane and friendly to the environment in which they operate.

\section{Starbucks:}

Starbucks has green advocates smiling about its "bean-to-cup" approach, which stresses top efficiency at each link of its global supply chain. By all measures the program appears to be a great success, with the company's decision to use coffee cup sleeves made of recycled paper saving roughly 78,000 trees per year 
since 2006. Starbucks has also partnered up with many environmental organizations, from Conservation International to the Earthwatch Institute, in efforts to do right by the communities it operates in.

\section{Coca-Cola:}

Coca-Cola has narrowed down 3 environmental goals on which to focus their efforts: water stewardship, sustainable packaging, and climate \& energy protection. Each of these initiatives is detailed and explained at their corporate website. In just a few years, Coca-Cola has already gotten itself involved in community recycling programs and a complete, sustainability-focused overhaul of its packaging designs.

\section{Continental Airlines:}

Continental Airlines has spent over $\$ 16$ billion in the last decade to replace its entire fleet of airplanes with more fuel-efficient ones, in addition to installing fuel-saving "winglets" that cut emissions $5 \%$ on its 737 model aircraft. Beyond that, nitrogen oxide emissions from Continental's busy Houston hub have been sliced by an astounding $75 \%$ since the year 2000. Continental might also be the only company with 12 full time "staff environmentalists" on the payroll who are constantly pairing up with engine manufacturers to design greener, more efficient processes into company operations. And is if this weren't enough, the company makes a point of sorting all of its trash to see what can be recycled.

\section{Wal-Mart:}

Possibly the most hated name in the entire green movement, Wal-Mart is now positioned to make all but the most dogmatic of its detractors eat their words. According to Sustainablog, Wal-Mart has launched an ambitious long-term plan to eventually power each and every one its stores using $100 \%$ renewable energy sources. According to the company's executives, Wal-Mart is committed to using its waste-eliminating corporate philosophy to make its own operations more eco-friendly than ever.

\section{PRIMARY DATA:}

A survey was conducted on the employees of the Fast Food giants in Mantri Mall in Malleshwaram, Bengaluru as to find out whether there is any impact of the general business ecosystem on the business which are conducting green business activities, and the below data was collected:

\begin{tabular}{|l|l|l|l|l|}
\hline Questions & Yes & $\begin{array}{l}\text { Perce } \\
\text { tage }\end{array}$ & $\begin{array}{c}\text { Percen } \\
\text { tage }\end{array}$ \\
\hline $\begin{array}{l}\text { Are you familiar with } \\
\text { the term green } \\
\text { business (sustainable } \\
\text { business)? }\end{array}$ & 16 & $59 \%$ & 11 & $41 \%$ \\
\hline $\begin{array}{l}\text { Are you aware of the } \\
\text { initiatives carried out } \\
\text { by your business to go } \\
\text { green? }\end{array}$ & 27 & $100 \%$ & 0 & $0 \%$ \\
\hline $\begin{array}{l}\text { Do you advertise/ } \\
\text { market/display the } \\
\text { initiatives? }\end{array}$ & 20 & $74 \%$ & 7 & $26 \%$ \\
\hline $\begin{array}{l}\text { Does it help you to } \\
\text { attract more customers? }\end{array}$ & 27 & $100 \%$ & 0 & $0 \%$ \\
\hline $\begin{array}{l}\text { Have you done anything } \\
\text { different which other } \\
\text { businesses haven't done } \\
\text { in order to go green? }\end{array}$ & 25 & $92 \%$ & 2 & $8 \%$ \\
\hline $\begin{array}{l}\text { Are there any other } \\
\text { green business } \\
\text { initiatives which are } \\
\text { to be carried out in } \\
\text { future by your } \\
\text { business? }\end{array}$ & & & & \\
\hline $\begin{array}{l}\text { Were there any } \\
\text { changes in the activi } \\
\text { ties of the business } \\
\text { after implementation } \\
\text { of the green business } \\
\text { activities? }\end{array}$ & 19 & $70 \%$ & 8 & $30 \%$ \\
\hline $\begin{array}{l}\text { Are there any draw } \\
\text {-backs or hurdles in } \\
\text { implementing green } \\
\text { business activities? }\end{array}$ & 4 & $15 \%$ & 23 & $85 \%$ \\
\hline
\end{tabular}


Were there any

responses from your

competitors after

implementing of green

business activities?

If yes, Did the response

benefit your businesses

and helped the purpose

of going green?

Did the implementation

of the green business

activities affect your

raw materials suppliers?

If yes, was it beneficial for your business?

Were there any changes

in the management?

If yes, did you as an

employee were

benefited by it?

Is there any separate

team to carry out the

green business activity?

If given an opportunity, would you recommend any changes in the present green business activities of your business?

Is there any policy where your business educates about going green?

Were there any negative impacts on your business because of implemen -tation of the green business activities?

Would you recommend your business to take up more green business activities?

9

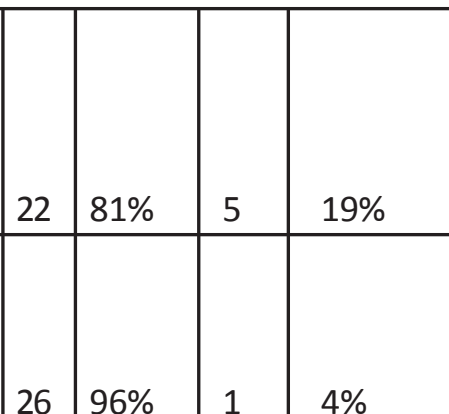

\begin{tabular}{|l|l|l|l|}
26 & $96 \%$ & 1 & $4 \%$ \\
\hline & & & \\
\hline
\end{tabular}

\begin{tabular}{|l|l|l|l|}
21 & $78 \%$ & 6 & $22 \%$ \\
\hline & & &
\end{tabular}

\begin{tabular}{|l|l|l|l|}
\hline 24 & $89 \%$ & 3 & $11 \%$ \\
\hline
\end{tabular}

\begin{tabular}{l|l|l|l}
19 & $70 \%$ & 8 & $30 \%$ \\
\hline
\end{tabular}

\begin{tabular}{|l|l|l|l|}
\hline 19 & $70 \%$ & 8 & $30 \%$ \\
\hline
\end{tabular}

\begin{tabular}{|l|l|l|l|}
\hline & & & \\
\hline & $0 \%$ & 27 & $100 \%$ \\
\hline
\end{tabular}

The above figures clearly suggest the weight-age green business activities have on the businesses. The yes and no percentages have been calculated to give a clear picture as to how the taking up of green business activities affects the businesses of the famous fast food giants.

I have tried to cover up all the major factors which would affect the business's daily activities. The employees were fairly co-operative and on the basis of their response and the information provided by them by filling up the questionnaire, the below findings have been listed.

\section{FINDINGS:}

1) The term 'green business' being a recently introduced term in the business world, many do not know it unless and until explained about it.

2) Most of the green activities are similar in nature when compared.

3) The employees are not considered or involved while taking up any green activity.

4) The regular employees are the one who carry out these activities.

5) The advertisements of the green initiatives are not done publicly. It is only known by the customers who visit these businesses.

6) There are mostly positive effects by the external environment of the business which has proven to be beneficial for them.

7) The internal environment has not changed much by the implementation of the green activities.

8) Point no.6 and 7 suggest that the businesses are not doing enough which could bring about a change in the business world.

9) There are changes to be made in the current green business activities carried out by the business.

10) There are only a few plans to take up some other green activities.

\section{SUGGESTIONS}

1) There should be some different activities to contribute to the environment which are not common in nature. 
2) There should be a different team for conducting the green activities so that the business can be properly concentrated and it also reduces the burden from the full time employees.

3) There should also be a proper research as to what are the actual basic needs which are not being fulfilled by the business's environment and efforts to reduce that gap should be done.

\section{REFERENCES}

1) Cooney, S. (2008). Build a Green Small Business: PROFITABLE WAYS TO BECOME AN ECOPRENEUR. New York, McGraw-Hill. 256 p.
2) Elkington, John) (DOI: 10.2307/41165746) TOWARDS A SUSTAINABLE CORPORATION: WINWIN BUSINESS STRATEGIES FOR SUSTAINABLE DEVELOPMENTVol. 36 (pp. 90-100).

SUSTAINABLE BUSINESS,(2016) https:// en.m.wikipedia.org

GREEN BUSINESS DEFINITION, www.businessdictionary.com

GREEN BUSINESS:OPPORTUNITIES AND CHALLENGES, (2013) www.mdpi.com 